\title{
Fasting blood glucose and newborn birth weight of non-
}

\section{diabetic Sudanese women [version 1; peer review: 1 approved,}

\section{1 approved with reservations]}

\author{
Abdelmageed Elmugabil ${ }^{1}$, Duria A. Rayis², Ishag Adam (1D2, Mohamed F. Lutfi ${ }^{3}$ \\ ${ }^{1}$ Faculty of Medicine, El Imam El Mahdi University, Kosti, Sudan \\ ${ }^{2}$ Faculty of Medicine, University of Khartoum, Khartoum, Sudan \\ ${ }^{3}$ Faculty of Medicine and Health Sciences, Alneelain University, Khartoum, Sudan
}

\section{V1 First published: 11 Apr 2016, 5:641 \\ https://doi.org/10.12688/f1000research.8416.1 \\ Latest published: 11 Apr 2016, 5:641 \\ https://doi.org/10.12688/f1000research.8416.1}

\begin{abstract}
Background

Although risk factors for abnormal birth weight has been extensively investigated, whether the physiological range of glucose tolerance affects birth weight in non-diabetic mothers needs to be verified by further research.

\section{Objectives}

To assess the effect of maternal sociodemographic characteristics, obstetric and anthropometric measurements, fasting and 2-hour blood glucose levels on birth weight.

\section{Methods}

One hundred and thirty four women were followed from early pregnancy until delivery at Saad Abualila Hospital, Khartoum, Sudan. Fasting and 2-hour glucose levels following administration of $75 \mathrm{~g}$ oral glucose was performed in the third trimester. Association between birth weight and maternal sociodemographic characteristics, obstetric and anthropometric measurements, haemoglobin, fasting and 2-hour blood glucose levels were assessed by linear regression analysis.

\section{Results}

The mean (SD) birth weight was 3127.7 (480.0) $\mathrm{g}$, while the $10^{\text {th }}$ and 90 th centile were 2500 and $3800 \mathrm{~g}$, respectively. There was no significant difference in the birth weight between male $(n=73)$ and female $(n=61)$ newborns [3167.8 (545.0) vs 3068.9 (384.0) $\mathrm{g}, \mathrm{P}=0.196$ ]. Likewise there was no significant difference in the birth weight of newborns born to primipara and multipara mothers [3101.7 (529.0) g vs 3151.4 (432.0) g, $\mathrm{P}=0.551]$.

Linear regression analysis demonstrated significant association between fasting blood glucose and birth weight (20 g, $\mathrm{P}=0.028$ ). None of the other maternal/fetal characteristics was associated with birth weight, including maternal age, body mass index, gravidity, weight gain during pregnancy, interpregnancy interval, history of

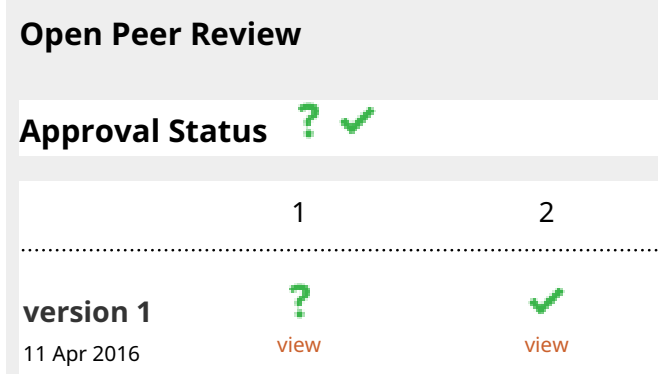

1. Angela E Vinturache, University of Calgary, Calgary, Canada

2. Tsi Njim, University of Buea, Buea,

Cameroon

Any reports and responses or comments on the article can be found at the end of the article. 
miscarriage, haemoglobin level, blood pressure, fetal gender and gestational age.

\section{Conclusion}

In this study fasting blood glucose was found to be predictor of birth weight among neonates of non-diabetic Sudanese mothers.

Keywords

birth weight, fasting blood glucose, non- diabetic, Sudan

Corresponding author: Ishag Adam (ishagadam@hotmail.com)

Competing interests: No competing interests were disclosed.

Grant information: The author(s) declared that no grants were involved in supporting this work.

Copyright: ( $) 2016$ Elmugabil A et al. This is an open access article distributed under the terms of the Creative Commons Attribution License, which permits unrestricted use, distribution, and reproduction in any medium, provided the original work is properly cited. Data associated with the article are available under the terms of the Creative Commons Zero "No rights reserved" data waiver (CC0 1.0 Public domain dedication).

How to cite this article: Elmugabil A, Rayis DA, Adam I and Lutfi MF. Fasting blood glucose and newborn birth weight of nondiabetic Sudanese women [version 1; peer review: 1 approved, 1 approved with reservations] F1000Research 2016, 5:641 https://doi.org/10.12688/f1000research.8416.1

First published: 11 Apr 2016, 5:641 https://doi.org/10.12688/f1000research.8416.1 


\section{Introduction}

Abnormal birth weight constitutes a major risk factor for a wide spectrum of childhood morbidities ${ }^{1}$. Low birth weight is more prevalent in developing compared with developed countries ${ }^{2,3}$. It is commonly associated with several maternal sociodemographic, nutritive, medical and obstetrical risk factors ${ }^{4}$ including poor socioeconomic status ${ }^{5}$, inadequate antenatal care ${ }^{6}$, short interpregnancy interval ${ }^{7}$, history of miscarriage ${ }^{8}$, preterm labour $^{9}$, low prepregnancy weight ${ }^{10,11}$ or weight gain during pregnancy ${ }^{12}$, anaemia ${ }^{13}$, hypoglycaemia ${ }^{14}$, hypertension ${ }^{15}$ and certain infectious diseases during pregnancy ${ }^{16,17}$. Alternatively, gestational diabetes and past history of fetal macrosomia are the major predictors of high birth weight $^{18}$.

Previous reports showed accumulating evidence for chronic maternal hypoglycaemia ${ }^{14}$ and hyperglycaemia ${ }^{18}$ as important risk factors for low and high birth weight respectively. Accordingly, the effect of glycaemic control on birth weight seems to extend into the physiological range of glucose tolerance. However, the scientific evidence for this hypothesis remains to be verified by further research. For further exploration of this hypothesis we designed this study to assess the association between glycaemic control and birth weight in non-diabetic Sudanese women. In addition, the influences of maternal sociodemographic characteristics, obstetric history and anthropometric measurements on birth weight were assessed. Scarcity of Sudanese studies on the scope of the present objectives gives this study exceptional importance, especially if we consider the extensive research exploring risk factors of abnormal birth weight worldwide.

\section{Methods}

A longitudinal study was conducted at Saad Abualila Hospital (Khartoum, Sudan) during the period of January-October 2014. Saad Abualila Hospital is a tertiary semi-private hospital governed by the Faculty of Medicine, University of Khartoum. After giving informed consent, eligible women were enrolled in the study in their first trimester or during the first antenatal visit. Inclusion criteria were: early, singleton pregnancy and willingness to participate in the study. Women with diabetes mellitus, hypertension or any other chronic disease were excluded from the study. A questionnaire was used to gather data from each pregnant women on her age, parity, educational level (illiterate, primary school education or secondary school and above education), occupation (housewife or working mother), gestational age calculated in weeks. Weight and height were determined, and body mass index (BMI) was calculated and expressed as weight in kilograms divided by the square of height in meters. The gestational age was calculated from the last menstrual period and confirmed by early ultrasound. The participants were followed up in the antenatal clinic until delivery; on every visit their weight was recorded and the weight gained during pregnancy was calculated from maximum weight gained and the weight during the first visit. Iron plus folic acid $(60 \mathrm{mg}$ iron + $400 \mu \mathrm{g}$ folic) were prescribed to the women. In the third trimester a $75 \mathrm{gm}$ glucose tolerance test was performed and haemoglobin A1C was evaluated for all the participants.

Fasting and 2-hour glucose were measured from venous blood with a colorimetric method. The World Health Organization (WHO)
1999 criteria (fasting plasma glucose $\geq 7.0 \mathrm{mmol} / \mathrm{L}$ or 2 -hour postprandial glucose $\geq 7.8 \mathrm{mmol} / \mathrm{L}$ ) was used to diagnose diabetes ${ }^{19}$.

The newborns were weighed immediately following birth to the nearest $10 \mathrm{~g}$ on a Salter scale, which was checked for accuracy on a weekly basis. The gender of each newborn was recorded.

A total sample size of 130 participants was calculated to investigate the factors influencing normal birth weight (2500-4000g). In order to investigate low birth weight and macrosomia, a much larger sample size is needed. A formula was used to calculate the mean of the proposed variables (birth weight) that would provide $80 \%$ power to detect a $5 \%$ difference at $\alpha=0.05$, with an assumption that complete data might not be available for $12 \%$ of participants.

\section{Statistics}

SPSS for Windows (version 16.0) was used for data analyses. Studied variables were described with means $(\mathrm{M})$ and standard deviations (SD). Proportions of the studied groups were expressed in percentages (\%). The difference of mean (SD) of the birth weight was compared between two groups using a T-test. Linear regression analyses were performed where birth weight was the dependent variable and socio-demographic parameters (age, parity, job, and residence), hemoglobin, blood glucose and hemoglobin A1C levels, interpregnancy interval, gestational age, birth weight, maternal BMI and weight gain were the independent variables. $\mathrm{P}<0.05$ was considered statistically significant.

\section{Ethics}

The study received ethical clearance from the Research Board at the Department of Obstetrics and Gynaecology, Faculty of Medicine, University of Khartoum, Sudan.

\section{Results}

Dataset 1. Raw dataset for Elmugabil et al., 2016 'Fasting blood glucose and birth weight in non-diabetic Sudanese women'

http://dx.doi.org/10.5256/f1000research.8416.d118225

Basic characteristics of the women were gathered using questionnaires. age = age years, Residence ( $1=$ rural, $0=$ urban); miscarriage $=$ history of miscarriage $(1=$ yes, $0=$ no); stillbirth $=$ history of still birth $(1=$ yes, $0=$ no); education $(0=$ none, 1 = primary, 2 = secondary, 3 university and above); Job ( 0 = housewife, $1=$ employee); $\mathrm{Wt}=$ weight (Maternal; $\mathrm{kg}) ; \mathrm{Ht}=$ height (Maternal; $\mathrm{cm}$ ), IPI (interpregnancy interval in months); bloodgroup (Maternal): $0=A, 1=B, 2=A B 3=0$ ); ahb = hemoglobin at early pregnancy; $\mathrm{bhb}=$ hemoglobin at later pregnancy; hba1c = hemoglobin $\mathrm{A} 1 \mathrm{c}$ birthwt = birthweight (Child; g); gestweeks = Gestational weeks; gender $(0=$ male; 1 = female); wtgain = weight gain, fbsugarmole = fasting blood glucose in $\mathrm{mmol} / \mathrm{L}$; onegarmole = one hour blood glucose in $\mathrm{mmol} / \mathrm{L}$; twogarmole = two hours glucose in $\mathrm{mmol} / \mathrm{L}$.

Out of 178 pregnant women who were enrolled initially, 7 and 5 had diabetes and hypertension, respectively and were excluded. There were $32(18.0 \%)$ participants lost during follow-up due to address change. The remaining $134(75.2 \%)$ women completed the follow-up till the delivery and their data were included during statistical analysis. 
Around half of these women were primipara $(64.0,47.8 \%)$, the majority were housewives $(101,75.4 \%)$ and few of them of rural residence $(14,10.4 \%)$. Thirty three $(24.6 \%)$ and four $(3.0 \%)$ of the studied women $(n=134)$ had history of miscarriage and stillbirth, respectively. The basic characteristics of the participants are shown in Table 1.

The birth weight range was $1650-4500 \mathrm{~g}$ and the mean (SD) was 3127.7(480.0) g, while the 10th and 90th centile was 2500 and 3800 g, respectively. Six $(4.5 \%)$ and five $(3.7 \%)$ newborns were small for gestational (SGA) age and larger for gestational age (LGA), respectively.

There was no significant difference in the birth weight between male $(\mathrm{n}=73,3167.8(545.0) \mathrm{g})$ and female $(\mathrm{n}=61,3068.9(384.0) \mathrm{g}$, $\mathrm{P}=0.196]$ newborns. Likewise there was no significant difference in the birth weight of newborns born to primipara and multipara mothers [3101.7 (529.0) g vs 3151.4 (432.0) g, $\mathrm{P}=0.551$ ].

In linear regression, only the fasting blood glucose was significantly associated with birth weight ( $20 \mathrm{~g}, \mathrm{P}=0.028$; Table 2$)$.

\section{Discussion}

It is evident from the present results that maternal fasting blood glucose level was associated with birth weight among newborns of non-diabetic mothers we studied. According to the current data, maternal fasting blood glucose level had the highest influence on birth weight compared with maternal sociodemographic characteristics, obstetric history and anthropometric measurements. Previous reports exploring the influences of glucose homeostasis on birth weight were mostly based on newborns of diabetic mothers ${ }^{18,20}$. However, there is evidence that the association of chronic hyperglycemia and macrosomia extends into the physiological range of glucose tolerance ${ }^{21-24}$. There is considerable debate

Table 1. Mean (SD) of basic characteristic of the enrolled pregnant women $(n=63)$.

\begin{tabular}{|l|c|}
\hline Variable & Mean (SD) \\
\hline Age, years & $28.3(5.5)$ \\
\hline Gravidity & $2.7(3.1)$ \\
\hline $\begin{array}{l}\text { Interpregnancy interval, } \\
\text { months (70) }\end{array}$ & $38.6(20.4)$ \\
\hline Body mass index & $27.7(6.1)$ \\
\hline Hemoglobin, gm/dl & $10.7(1.2)$ \\
\hline Fasting blood glucose, mmol/L & $3.7(0.4)$ \\
\hline $\begin{array}{l}\text { Two hours blood glucose, } \\
\text { mmol/L }\end{array}$ & $6.3(1.6)$ \\
\hline Hemoglobin A1C, \% & $4.3(1.0)$ \\
\hline Gestational age, weeks & $38.9(1.4)$ \\
\hline Birth weight, g & 3127.7 \\
\hline Weight gain, kg & $(480.0)$ \\
\hline
\end{tabular}

Table 2. Linear regression analyses of the factors and birth weight in Khartoum, Sudan.

\begin{tabular}{|l|c|c|c|}
\hline Variables & Coefficient & $\begin{array}{c}\text { Standard } \\
\text { error }\end{array}$ & P \\
\hline Age & 0.023 & 0.030 & 0.442 \\
\hline Gravidity & -0.015 & 0.018 & 0.402 \\
\hline Rural residence & 0.132 & 0.406 & 0.749 \\
\hline History of miscarriage & 0.133 & 0.350 & 0.707 \\
\hline Housewives & -0.361 & 0.245 & 0.157 \\
\hline Interpregnancy interval & -0.009 & 0.007 & 0.204 \\
\hline Hemoglobin at early & -0.134 & 0.111 & 0.244 \\
\hline pregnancy & -0.011 & 0.102 & 0.916 \\
\hline Hemoglobin & 0.020 & 0.008 & 0.028 \\
\hline Fasting blood glucose & 0.000 & 0.005 & 0.924 \\
\hline Two hours blood glucose* & 0.114 & 0.096 & 0.247 \\
\hline Hemoglobin A1C & 0.189 & 0.191 & 0.336 \\
\hline Gender & 0.028 & 0.062 & 0.659 \\
\hline Gestational age & 0.027 & 0.018 & 0.153 \\
\hline Body mass index & 0.012 & 0.015 & 0.427 \\
\hline Weight gain & & & \\
\hline
\end{tabular}

- corrected for fasting blood glucose

on the ideal approach for biochemical diagnosis of gestational diabetes $^{25}$. Likewise, the studies that documented the association between hyperglycemia and high birth weight were unable to provide a clear cutoff for the glucose level above which the risk of macrosomia increased ${ }^{26}$. In a prospective study, the results of $75 \mathrm{~g}$ oral glucose tolerance tests at the $17^{\text {th }}$ and $32^{\text {nd }}$ week of gestation were compared in non-diabetic women attending one antenatal out-patient care unit ${ }^{21}$. Although the studied women did not fulfil the diagnostic criteria of gestational diabetes mellitus, the mean +2 standard deviations of glucose level after 2 hour of $75 \mathrm{~g}$ oral glucose was $8.0 \mathrm{mmol} / \mathrm{l}(144 \mathrm{mg} / \mathrm{dl})$ at $32^{\text {nd }}$ week. The significantly impaired glucose level at the $32^{\text {nd }}$ week compared with the $17^{\text {th }}$ week of gestation led the authors to recommend revision of the cut-off values used for diagnosis of gestational diabetes mellitus. The study also demonstrated association between maternal glucose level and weight gain $>18 \mathrm{~kg}$ during pregnancy, macrosomia, prematurity and other maternal/fetal complications. Another study assessing the relationship between birth weight and maternal glycemic control during normal pregnancy was able to confirm maternal weight (before pregnancy and at term), gestational age, parity, and newborn gender as significant independent predictors of birth weight ${ }^{22}$. According to the same study, fasting blood glucose level was positively associated with birth weight independent of the other sociodemographic and obstetric characteristics of the studied mothers. This implication was further supported by Langhoff-Roos et al. who attribute $27 \%$ of the variation in newborn birth weight to maternal fasting blood glucose and lean body mass ${ }^{23}$. Other reports also demonstrated that even within normal range variations of maternal glucose homeostasis can affect growth and development of the fetus ${ }^{24}$. 
Hoegsberg et al. found no difference in glucose tolerance between mothers of macrosomic and normal infants, though macrosomic infants had significantly higher insulin levels than the control infants ${ }^{27}$. A possible explanation for macrosomia in such conditions may be fetal pancreatic beta-cell hypersensitivity to subtle hyperglycemia and subsequent fetal hyperinsulinemia ${ }^{28}$. Alternatively, an inverse relationship between birth weight and maternal insulin level was demonstrated when 134 normotensive, non-obese, nondiabetic mothers were studied at the $27^{\text {th }}$ week of gestation ${ }^{22}$. The same study confirmed an inverse relationship between insulin/ glucose ratio and birth weight; however, glucose levels were comparable in all quintiles of insulin/glucose ratio. In addition, birth weight was significantly decreased in the upper insulin/glucose quintile when compared to the other quintiles. The study concluded that maternal insulin level was associated with birth weight independently of the state of the maternal glycemic control.

It is worth mentioning that previous studies reported significant influences of maternal age ${ }^{29}$, gravidity ${ }^{30}$, work $^{31}$, interpregnancy interval $^{7}$, history of miscarriage ${ }^{32}$, hemoglobin level ${ }^{13}$, blood pressure $^{15}$, BMI $^{10,11}$, weight gain during pregnancy ${ }^{12}$, fetal gender ${ }^{33}$ and gestational age ${ }^{34}$ on fetal growth; however, none of these parameters were associated with birth weight in the present study.

Limitations of this study include lack of insulin measurements among the pregnant women we studied. Combined evaluation of fasting insulin and glucose concentrations is likely to offer better background on insulin resistance among the studied mothers ${ }^{35}$. Moreover, it will enable more clarification whether hyperinsulinemia or hyperglycemia has more influence on newborn birth weight $^{22}$.

\section{Conclusion}

The present results add a strong evidence for the important role of fasting blood glucose as an indicator of glycemic control in prediction of birth weight among neonates of non-diabetic mothers. According to the current data, maternal fasting blood glucose level had the highest influence on birth weight compared with maternal obstetric history, anthropometric measurements and sociodemographic characteristics.

\section{Consent}

Written informed consent for publication of their clinical details was obtained from the patients.

\section{Data availability}

F1000Research: Dataset 1. Raw dataset for Elmugabil et al., 2016 'Fasting blood glucose and birth weight in non-diabetic Sudanese women', 10.5256/f1000research.8416.d118225 35

\section{Author contributions}

$\mathrm{AE}$ and IA coordinated and carried out the study. DAR and MFL participated in the statistical analysis. AE and DAR participated in the clinical work. All the authors have read and approved the final version of this manuscript.

\section{Competing interests}

No competing interests were disclosed.

\section{Grant information}

The author(s) declared that no funding was involved in supporting this work.
1. Feresu SA, Harlow SD, Woelk GB: Risk Factors for Low Birthweight in Zimbabwean Women: A Secondary Data Analysis. Thorne C, ed. PLOS One. 2015; 10(6): e0129705.

PubMed Abstract | Publisher Full Text | Free Full Text

2. Islam MM: Increasing Incidence of Infants with Low Birth Weight in Oman. Sultan Qaboos Univ Med J. 2015; 15(2): e177-e183. PubMed Abstract | Free Full Text

3. Chen Y, Li G, Ruan Y, et al:: An epidemiological survey on low birth weight infants in China and analysis of outcomes of full-term low birth weight infants. BMC Pregnancy Childbirth. 2013; 13: 242. PubMed Abstract | Publisher Full Text | Free Full Text

4. Valero De Bernabé J, Soriano T, Albaladejo R, et al:: Risk factors for low birth weight: a review. Eur J Obstet Gynecol Reprod Biol. 2004; 116(1): 3-15. PubMed Abstract | Publisher Full Text

5. Kader M, Perera NK: Socio-economic and nutritional determinants of low birth weight in India. N Am J Med Sci. 2014; 6(7): 302-308. PubMed Abstract | Publisher Full Text | Free Full Text

6. Mumbare SS, Maindarkar G, Darade R, et al:: Maternal risk factors associated with term low birth weight neonates: a matched-pair case control study. Indian Pediatr. 2012; 49(1): 25-8. PubMed Abstract | Publisher Full Text

7. Zhu BP: Effect of interpregnancy interval on birth outcomes: findings from three recent US studies. Int J Gynaecol Obstet. 2005; 89(Suppl 1): S25-33. PubMed Abstract | Publisher Full Text

8. Poorolajal J, Cheraghi P, Cheraghi Z, et al.: Predictors of miscarriage: a matched case-control study. Epidemiol Health. 2014; 36: e2014031. PubMed Abstract | Publisher Full Text | Free Full Text
9. Gulati S, Andrews CA, Apkarian AO, et al:: Effect of gestational age and birth weight on the risk of strabismus among premature infants. JAMA Pediatr. 2014 168(9): 850-6.

PubMed Abstract | Publisher Full Text | Free Full Text

10. Adam I, Babiker S, Mohmmed AA, et al.: Low body mass index, anaemia and poor perinatal outcome in a rural hospital in eastern Sudan. $J$ Trop Pediatr. 2008; 54(3): 202-4.

PubMed Abstract | Publisher Full Text

11. Elhassan $E M$, Abbaker $A O$, Haggaz $A D$, et al:: Anaemia and low birth weight in Medani, Hospital Sudan. BMC Res Notes. 2010; 3: 181 PubMed Abstract | Publisher Full Text | Free Full Text

12. Shrestha I, Sunuwar L, Bhandary S, et al.: Correlation between gestational weight gain and birth weight of the infants. Nepal Med Coll J. 2010; 12(2): 106-9. PubMed Abstract

13. Haggaz AD, Radi EA, Adam I: Anaemia and low birthweight in western Sudan Trans R Soc Trop Med Hyg. 2010; 104(3): 234-6. PubMed Abstract | Publisher Full Text

14. Vadakekut ES, McCoy SJ, Payton ME: Association of maternal hypoglycemia with low birth weight and low placental weight: a retrospective investigation. J Am Osteopath Assoc. 2011; 111(3): 148-52. PubMed Abstract

15. Ali AA, Rayis DA, Abdallah TM, et al.: Severe anaemia is associated with a higher risk for preeclampsia and poor perinatal outcomes in Kassala hospital, eastern Sudan. BMC Res Notes. 2011; 4: 311. PubMed Abstract | Publisher Full Text | Free Full Text

16. Batran SE, Salih MM, Elhassan EM, et al:: CD20, CD3, placental malaria infections and low birth weight in an area of unstable malaria transmission in 
Central Sudan. Diagn Pathol. 2013; 8: 189.

PubMed Abstract | Publisher Full Text | Free Full Text

17. Mohammed AH, Salih MM, Elhassan EM, et al.: Submicroscopic Plasmodium falciparum malaria and low birth weight in an area of unstable malaria transmission in Central Sudan. Malar J. 2013; 12: 172 PubMed Abstract | Publisher Full Text | Free Full Text

18. Mohammadbeigi A, Farhadifar F, Soufi zadeh N, et al.: Fetal macrosomia: risk factors, maternal, and perinatal outcome. Ann Med Health Sci Res. 2013; 3(4): $546-550$.

PubMed Abstract | Publisher Full Text | Free Full Text

19. Gabir MM, Hanson RL, Dabelea D, et al: The 1997 American Diabetes Association and 1999 World Health Organization criteria for hyperglycemia in the diagnosis and prediction of diabetes. Diabetes Care. 2000; 23(8): 1108-1112. PubMed Abstract | Publisher Full Text

20. Yang YD, Zhai GR, Yang HX: [Factors relevant to newborn birth weight in pregnancy complicated with abnormal glucose metabolism]. Zhonghua Fu Chan Ke Za Zhi. 2010; 45(9): 646-51.

PubMed Abstract

21. Agardh CD, Aberg A, Nordén NE: Glucose levels and insulin secretion during a 75 g glucose challenge test in normal pregnancy. J Intern Med. 1996; 240(5): 303-9.

PubMed Abstract | Publisher Full Text

22. Breschi MC, Seghieri G, Bartolomei G, et al.: Relation of birthweight to maternal plasma glucose and insulin concentrations during normal pregnancy. Diabetologia. 1993; 36(12): 1315-21. PubMed Abstract | Publisher Full Text

23. Langhoff-Roos J, Wibell L, Gebre-Medhin M, et al:: Maternal glucose metabolism and infant birth weight: a study in healthy pregnant women. Diabetes Res. 1988; 8(4): 165-70. PubMed Abstract

24. Farmer G, Russell G, Hamilton-Nicol DR, et al.: The influence of maternal glucose metabolism on fetal growth, development and morbidity in 917 singleton pregnancies in nondiabetic women. Diabetologia. 1988; 31(3): 134-41. PubMed Abstract | Publisher Full Text

25. Agarwal MM: Gestational diabetes mellitus: An update on the current international diagnostic criteria. World J Diabetes. 2015; 6(6): 782-791. PubMed Abstract | Publisher Full Text | Free Full Text

26. Hartling L, Dryden DM, Guthrie A, et al:: Screening and diagnosing gestational diabetes mellitus. Evid Rep Technol Assess (Full Rep). 2012; (210): 1-327. PubMed Abstract | Free Full Text

27. Hoegsberg B, Gruppuso PA, Coustan DR: Hyperinsulinemia in macrosomic infants of nondiabetic mothers. Diabetes Care. 1993; 16(1): 32-6. PubMed Abstract | Publisher Full Text

28. Pinar H, Pinar T, Singer DB: Beta-cell hyperplasia in macrosomic infants and fetuses of nondiabetic mothers. Pediatr Dev Pathol. 2000; 3(1): 48-52. PubMed Abstract

29. Shmueli A, Cullen MR: Birth weight, maternal age and education: new observations from Connecticut and Virginia. Yale J Biol Med. 1999; 72(4): 245-258.

PubMed Abstract | Free Full Text

30. Muula AS, Siziya S, Rudatsikira E: Parity and maternal education are associated with low birth weight in Malawi. Afr Health Sci. 2011; 11(1): 65-71. PubMed Abstract | Free Full Text

31. Zhu JL, Hjollund $\mathrm{NH}$, Olsen J, et al:: Shift work, duration of pregnancy, and birth weight: the National Birth Cohort in Denmark. Am J Obstet Gynecol. 2004 191(1): 285-91.

PubMed Abstract | Publisher Full Text

32. Poorolajal J, Cheraghi $\mathrm{P}$, Cheraghi $\mathrm{Z}$, et al:: Predictors of miscarriage: a matched case-control study. Epidemiol Health. 2014; 36: e2014031. PubMed Abstract | Publisher Full Text | Free Full Text

33. Veiga-Lopez A, Kannan K, Liao C, et al:: Gender-Specific Effects on Gestationa Length and Birth Weight by Early Pregnancy BPA Exposure. J Clin Endocrinol Metab. 2015; 100(11): E1394-403.

PubMed Abstract | Publisher Full Text | Free Full Text

34. Preethi BL, Jaisri G, Kumar KM, et al:: Assessment of insulin resistance in normoglycemic young adults. Fiziol Cheloveka. 2011; 37(1): 118-25. PubMed Abstract

35. Elmugabil A, Rayis D, Adam I, et al.: Dataset 1 in: Fasting blood glucose and newborn birth weight of non-diabetic Sudanese women. F1000Research. 2016. Data Source 


\section{Open Peer Review}

\section{Current Peer Review Status:}

\section{Version 1}

Reviewer Report 25 January 2017

https://doi.org/10.5256/f1000research.9060.r19645

(C) 2017 Njim T. This is an open access peer review report distributed under the terms of the Creative Commons Attribution License, which permits unrestricted use, distribution, and reproduction in any medium, provided the original work is properly cited.

\section{Tsi Njim}

Department of Internal Medicine and Paediatrics, University of Buea, Buea, Cameroon

Congratulations to the authors for their efforts in pushing this through. Despite the small sample size, the work provides an insight into the complexities surrounding glycaemia and birth weight and hopefully provides the base for more research. It is context-specific to Sudan where much research on the issue is yet to be done.

Competing Interests: No competing interests were disclosed.

\section{I confirm that I have read this submission and believe that I have an appropriate level of expertise to confirm that it is of an acceptable scientific standard.}

Reviewer Report 27 June 2016

\section{https://doi.org/10.5256/f1000research.9060.r14106}

(C) 2016 Vinturache A. This is an open access peer review report distributed under the terms of the Creative Commons Attribution License, which permits unrestricted use, distribution, and reproduction in any medium, provided the original work is properly cited.

\section{Angela E Vinturache}

Department of Physiology and Pharmacology, University of Calgary, Calgary, AB, Canada

In the study "Fasting blood glucose and newborn birth weight of non- diabetic Sudanese women" A. Elmugabil et $a$ l aimed to assess the relationship between maternal sociodemographic and obstetrics characteristics and blood glucose and birth weight. The authors report an association between fasting blood glucose and birth weight (BW) and no association between other variables and BW. There are several concerns with this study:

1. The title does not accurately reflect the objectives of the study 
2. The objective of the study does not match the methodology; the study was designed to study an association and not causality/effects

\section{Methodology:}

i) Study designed: there are no information provided on survey data collection; not clear if the sample included both preterm and term pregnancies; what test was used for OGTT, if the test is validated, at what gestational age was the test done; how the correction for $2 \mathrm{~h}$ blood glucose was done and what was the rationale behind this correction; the term "early" pregnancy and US should be defined;

ii) Statistical analysis is not sound as the authors used both continuous and categorical variables as independent variables in the linear regression analyses; GA is a confounder for the relationship between BMI, GWG and BW and should be controlled for.

4. Results section do not report on how many women had normal or abnormal OGTT tests; it is not clear what GA was included in Table 1

5. Most part of the comments from the Discussion section are tangential to the topic; the authors do not provide any explanation for their findings and the differences between their results and the data from literature.

6. Part of the Conclusions of the study are incorrect.

Competing Interests: No competing interests were disclosed.

I confirm that I have read this submission and believe that I have an appropriate level of expertise to confirm that it is of an acceptable scientific standard, however I have significant reservations, as outlined above. 
The benefits of publishing with F1000Research:

- Your article is published within days, with no editorial bias

- You can publish traditional articles, null/negative results, case reports, data notes and more

- The peer review process is transparent and collaborative

- Your article is indexed in PubMed after passing peer review

- Dedicated customer support at every stage

For pre-submission enquiries, contact research@f1000.com 